Отримано: 26 квітня 2019 р.

Прорецензовано: 6 травня 2019 р.

Прийнято до друку: 7 травня 2019 р.

e-mail: mariia.avgustiuk@oa.edu.ua

DOI: $10.25264 / 2415-7384-2019-8-57-60$
Avhustiuk M. M. Peculiarities of efficient metacognitive monitoring of university student's learning activity. Наукові записки Національного університету «Острозька академія». Серія «Психологія» : науковий журнал. Острог : Вид-во НаУОА, червень 2019. № 8. C. 57-60.

\title{
PECULIARITIES OF EFFICIENT METACOGNITIVE MONITORING OF UNIVERSITY STUDENTS' LEARNING ACTIVITY
}

The article is dedicated to the theoretical description of the peculiarities of formation of the skills of efficient metacognitive monitoring of the learning activity of university students. In particular, we highlighted negative impacts of the illusion of knowing in the learning activity of university students such as inadequate self-estimation of the learning results, metacognitive incompetence, inability to estimate actual level of real understanding of students' own knowledge skills and strategies, inability to differentiate the illusory knowledge and not illusory one, etc. We also provided an analysis of importance of effective metacognitive monitoring skills formation of the learning activity of university students. It is approved that such formation is possible because of stimulation of students' learning motivation, formation of adequate self-estimation, development of high levels of reflexivity, development of students' capability of individual estimation of their own activity and its results, development of abilty to provide effective feedback, teaching the ways how to use the processes of metacognitive monitoring with an aim to understand their own attitude towards the learning disciplines and the chosen speciality. Possible perspectives of future investigations of the problem are also described.

Key words: confidence, illusion of knowing, metacognitive monitoring, learning activity, judgments.

\section{Августюк Марія Миколаївна,}

кандидат психологічних наук, старший викладач кафедри міжнародних відносин

Національного університету «Острозька академія»

\section{ОСОБЛИВОСТІ ФОРМУВАННЯ НАВИЧОК ЕФЕКТИВНОГО МЕТАКОГНІТИВНОГО МОНІТОРИНГУ НАВЧАЛЬНОЇ ДІЯЛЬНОСТІ СТУДЕНТІВ}

\begin{abstract}
Статтю присвячено вивченню особливостей формування навичок ефективного метакогнітивного моніторингу навчальної діяльності студентів. Зокрема, відзначено негативний вплив ілюзї знання в навчальній діяльності студентів, а саме неадекватну самооцінку результатів навчання, метакогнітивну некомпетентність, нездатність студентів об 'єктивно оцінити рівень реального розуміння власних знань і стратегій, нездатність диференціювати ілюзорне знання від неілюзорного тощо. Проаналізовано важливість формування навичок ефективного метакогнітивного моніторингу навчальної діяльності студентів. Установлено, щчо иее можливе завдяки стимулюванню у студентів навчальної мотивації, формуванню адекватної самооцінки, розвитку високих показників рефлексивності, розвитку здатності самостійно очінювати свою діяльність та їі результати, здатності до зворотного зв'язку, навчанню використовувати процеси метакогнітивного моніторингу для усвідомлення власного ставлення до тієі чи тісї навчальної дисципліни та до обраної спеціальності. Описано можливі перспективи подальших досліджень проблеми.
\end{abstract}

Ключові слова: упевненість, ілюзія знання, метакогнітивний моніторинг, навчальна діяльність, судження.

Formulation of the problem. The relevance of the studies of metaknowledge in general and specifically of the processes of metacognitive motivation is determined, first of all, by the tendency of many people to distort the understanding of what they know and what they do not really know, and also if they are competent in solving learning tasks. As the problem of knowledge overestimation is a comprehensive phenomenon in the modern system of education, the illusion of knowing also proves to be a conceptual problem in the learning process.

The realization of effective metacognitive monitoring lies in the responsibility of all participants of the learning process for a number of issues aimed at effective cooperation and retention of positive results. The learning activity of students requires not only the organization of work during some class activities, but also the development of appropriate skills to understand issues that are taken into account within the framework of the course, assimilation quality of the given information, and monitoring of the training process. These may help to form inevitably appropriate training characteristics for further self-organization.

An analysis of recent researches and publications. Some significant characteristics of metacognitive monitoring as a regulatory aspect of metaknowledge, its structural components, types, and influence on the learning process are illustrated in the works by L. Baker, A. Brown, A. Fomin, F. Jönsson, A. Karpov, M. Kashapov, A. Koriat, L. Narens, T. Nelson, J. Nietfeld, I. Pasichnyk, E. Savin and others. Separate factors of 
metacognitive monitoring are also studied in the researches of such scholars as S. Berry, M. Bradley, T. de Baker Rodel, T. Dotsevych, T. Dubovytska, V. Epstein, A. Glenberg, T. Ilina, R. Kalamazh, A. Karpov, T. Khomulenko, A. Koriat, S. Lichtenstein, R. Maki, J. Metcalfe, D. Moore, L. Narans, T. Nelson, J. Nietfeld, M. Parkinson, I. Pasichnyk, B. Pullford, H. Shraw, I. Skytiaieva, V. Voloshyna, A. Wilkinson, K. Zabrucky and others. However, in spite of a considerable number of studies, such an aspect as the study of factors of the effectiveness of metacognitive monitoring of student learning activities remains relevant.

The aim of the article is to conduct a theoretical analysis of important ways to promote the effectiveness of the processes of metacognitive monitoring of the learning activity of university students.

Theoretical background of the problem. It is theoretically concluded that the broad negative consequences of the illusion of knowing in the learning activity of university students are: inadequate self-assesment of the learning results; metacognitive incompetence of students' own knowledge, skills, and strategies; inability to adjust the level of the actual learning material; inability to revise the illusory knowledge from non-illusory one; ineffective development of time and attention while learning the material; spending insignificant amount of effort to search for a correct answer, or, on the contrary, the cost of unnecessarily used efforts [1].

We $[1 ; 6]$, in particular, have highlighted such ways of annihilation of the negative influence of the illusion of knowing on the effectiveness of students' learning activity: abstraction from already known material; substantial repetition of the learned material; identification of the problematic situation (presence of students' own points of view, representations, marks, experience, revealation and framing of the situation); motivation; feedback which is possible because of the discussion of the chosen answers; targeted training in doing tasks; assessment of information before the judgments of learning; self-report of the development of the perception of the truth of the actual knowledge, the composite components of which are self-estimation and self-questioning; use of different forms of control (from the teacher's side, self-control, mutual control, etc.).

Depending on J. Metcalfe and N. Kornell [8], the first step towards avoiding metacognitive monitoring mistakes should be the ability of students to abstract from the learning material they already know. However, it is not easy to do as students are reluctant to deny that they in fact have not learned properly yet the information given. In case thoroughly learned information is brought to the background, the students should be able to determine the degree of the learning the information still needed to be learned, in order to devote the learning time to its in-depth work. Making it effective is not always easy, but if someone succeeds, one can get high results. An important role is also played, in particular, by the ability to effectively plan learning activities, by motivation, etc.

The purpose of the identification of the problematic situation is to identify and quantify the current situation, to try to implement it and to provide further work on its solving. This is one of the most effective methods for suppressing confidence when coping with learning problems. As the basis of the approach serve contrasting views and ideas received during learning. An example of problem-solving (by A. Fomin [4]) can also be students' subjectivity to compare their own knowledge when they respond to test questions with objective test data that they receive from a teacher in the form of feetback. It is the feedback that is a condition for which it is advisable to increase the level and quality of the learning activity, to identify problems and to correct them in a more subtle way on the methodological background.

Due to J. Davidson, R. Daiser and R. Sternberg [4], metacognitive processes take part in the determination and identification of the problematic situation, as well as in the process of its representation by the learner. In its turn, the correct or wrong identification of the problematic situation, as well as adequate or inadequate representation of it, is an outstanding fact of the productivity of thinking. Misinterpretation of the prevailing situation may lead to the solving of the mistakenly taken into account problem, either to spend a lot of efforts and time to resolve an unnecessarily sophisticated problem. Attention should be also paid to the fact that the learners do not even perceive that their representation of the problematic situation does not correspond to the true essence, and the formalization of the problem contains distortions, or in general, it is foolishly accomplished. If the situation takes place, it can mean that inadequate metacognitive monitoring of the process of setting up and framing the problem is inevitable. Changes in metacognitive monitoring suggest metacognitive activity aimed at correcting improperly solved learning tasks $[1 ; 6]$.

To annihilate the illusion of knowing, as well as other metacognitive illusions, is regarded to be possible with the help of the given feedback (A. Butler, A. Glenberg, B. Pullford, and others), which contributes to the informing of the learner about the achieved state, even though this influence may be insignificant (S. Ward, H. Clark). Discussion of the chosen answers (A. Koriat, S. Lichtenstein, B. Fischhoff), changes in the structure of the sentences given (S. Bredart, K. Modolo, C. Townsend, E. Heit), targeted training in problem solving (T. Nietfeld, G. Schraw), estimation of different kinds of information before the metacognitive judgments of learning (J. Dunlosky, K. Rawson, E. Middleton) also play supplementary roles. Avoiding the illusion of knowing can be possible by giving students the possibility to do the test of measuring the level of their understanding, similar to the one that will be done after completing the whole process of learning (R. Bjork, L. Jacoby, C. Kelley). 
During auditory studies, individual works, home tasks activities, final control works aiming to fix previously gained knowledge during the course of the subject etc., students have to actively summarize and analyze, especially the things that were not understandable or difficult to understand and thus to learn, set themselves questions about the levels of importance and curiosity of the given information, produce any feasible ways how to use information in practice.

Being an active participant of the learning processes, an average student systematically compares the estimations of his / her own subjective confidence in the correctness of the coping with any learning task (estimates the coorectness of the done tasks, indicates the level of confidence in the correctness of the tasks, compares his / her previous foresight of the number of correctly done tasks with the results achieved, and also compares given level of confidence in every task to the received mark). Moreover, the student retains the objective success of the task. It is the feedback, and also taking into account the results of the particular trials and efforts in the further learning mutual interactions, that can positively influence the quality of all the work done.

Self-report suggests an overthrow in the development of the perception of the truth of the actual knowledge. Students will be able to achieve high-quality results by asking the question «How do I know?», «What do not I know?», «What should I know?» [7; 8]. The search of students on such questions stimulates better understanding of what they know and what they want to know. It is also important to foster students' skills in including the result of the learning activities in the general picture of the world of the learning activity and of themselves with the help of self-questioning of the type «How does the information cohere with my ideas of the world, and how have I personally changed during the process of the problem solution?».

This approach is one of the stages on the way to greater independence in learning and, consequently, in enhancing the effectiveness of the entire learning process. Moreover, the prospect implies a targeted development by the students of their own metacognitive activities (training of memory, thinking, intellect, development of the level of reflexivity, etc.), which are directly related to the formation of different methods of metacognitive judgments. It may also be effective to form the habit to the vivid vision what should be received at the end of the solution of the problem. It is inconceivable to target students on distinct understanding of the necessity of acquiring all the needed resources for successful coping with the task, as well as to delibirately control the stages of the decision making while doing the task and the quality of the received results $[1 ; 6]$.

One of the most important aspects of the self-report is the adequate self-estimation, which is aimed at framing adequate representations of the levels of available knowledge. Self-estimation of knowledge is the result of the improvement of the human being the level of the efficiency of the actual learning activity. The optimal (adequate) self-estimation means the correct interaction of a student all his / her abilities, skills and knowledge, presupposes a quite critical attitude towards oneself, desire to really overlook own failures and successes, attempts to set real goals and to pursue them. Adequate self-estimation usually leads to greater efficiency of metacognitive monitoring. The opposite actions of adequate self-estimation inadequately over- or undervalue self-estimation which often leads to the emergence of metacognitive illusions of confidence in knowing in the real absence of this knowledge (the illusion of knowing). The underlying causes are, in particular, violation of the process of self-regulation, and distortions of self-control $[1 ; 6]$.

In the sphere of pedagogics it is widely acknowledged that self-estimation is based on the external estimation of the teacher, but for doing this the teacher must be sufficiently competent in the field of the adequate assessments. The realization of the effective academic activity of the teacher helps to regulate the students' self-estimation, which can ensured with the following attributes: securing of adequate factors of personal estimations (partial marks); an emphasis on the successes achieved by students in the process of the learning activities; a retraining report on the learning activities of students and their results; changeable grounding and explanation of the marks $[2 ; 3 ; 5]$.

The thing that facilitates the formation of the effectiveness of students' self-organization, the activization of the learning activity, and the establishment of favorable relationships among all the participants of the learning activities is the use in the learning process of the methods of collective learning and mutual co-operation, which are inevitable condition of the formation of metacogntive abilities of students in the learning activities. In this case the teacher play the role of the consultant that knows properly personal and individual peculiarities of every student, is able to provide recommendations concerning the increase of the learning material effectiveness, organises the needed comfort conditions for students' self-learning, self-development and self-understanding, and also concerns the increase of the efficient collaboration among the students themselves.

With the aim to create the system of recommendations of metacognitive monitoring optimization the key aspects of the peculiarities of efficient metacognitive monitoring of university students' learning activity can be summurised in the following way (see Table 1): 
Key aspects of the peculiarities of efficient metacognitive monitoring of university students' learning activity

\begin{tabular}{|c|c|c|}
\hline $\begin{array}{c}\text { Individual, cognitive } \\
\text { and metacognitive characteristics } \\
\text { of students related to the reliability } \\
\text { of the metacognitive monitoring }\end{array}$ & $\begin{array}{l}\text { Formation of students' knowledge } \\
\text { about tasks and external stimuli }\end{array}$ & $\begin{array}{c}\text { Formation of effective metacognitive } \\
\text { monitoring skills }\end{array}$ \\
\hline $\begin{array}{l}\text { - learning motivation; } \\
\text { - general inner confidence; } \\
\text { - reflexivity; } \\
\text { - the degree of mastering knowledge; } \\
\text { - self-efficiency; } \\
\text { - metacognitive knowledge, activity and } \\
\text { involvement in the learning activity, etc. }\end{array}$ & $\begin{array}{l}\text { - peculiarities of the learning material; } \\
\text { - self-esteem; } \\
\text { - systematization; } \\
\text { - generalization; } \\
\text { - time spending; } \\
\text { - practice, etc. }\end{array}$ & $\begin{array}{l}\text { - abstraction from the already learned; } \\
\text { - identification of the problem; } \\
\text { - feedback; } \\
\text { - self report; } \\
\text { - strategy; } \\
\text { - motivation; } \\
\text { - estimation of the learning activity, etc. }\end{array}$ \\
\hline
\end{tabular}

Conclusion and prospects for further research. To sum up, the peculiarities of formation of the skills of efficient metacognitive monitoring of the learning activity of university students, first of all, depend on the stimulation of the learning motivation of the students, formation of their adequate self-estimation, development of high levels of reflexivity, ability to the feedback, etc. Besides, it is greatly needed to develop in students their ability to the self-estimation of their own learning activity and its results, teaching how to use the processes of metacognitive monitoring with the aim to understand their own attitude to the learned subject or even to the chosen speciality in general, that does not only promote efficient studying, but also helps to forming professional thinking.

The promising direction of research is the in-depth study of the influence of the illusion of knowing on metacognitive monitoring and control, and more thorough study of the factors of metacognitive monitoring of the students' learning activity. There is also a need to establish the conditions for the effective implementation of the accurate metacognitive judgments directly into the learning activity.

\section{References}

1. Августюк М. М. Ілюзія знання в метакогнітивному моніторингу навчальної діяльності студентів ВНЗ. Дис. ... канд. психол. наук:19.00.07. Острог, 2016. 316 с.

2. Бех І. Д. Проблема психічного розвитку особистості і удосконалення навчального процесу. Радянська школа. 1979. № 7. С. $28-33$.

3. Ковальчук 3. Я. Критерії оптимізації навчання у вищому навчальному закладі. Наукові записки. Серія «Психологія і педагогіка». Острог: Видавництво Національного університету «Острозька академія», 2013. C. $112-121$.

4. Фомин А. Е. Эвристика доступности и метакогнитивный мониторинг решения учебных задач студентами. Психология: Вестник Брянского госуниверситета. 2012. № 1. С. 175-179.

5. Шевченко Н. Ф., Шевченко А. І. Успішність студентів як проблема педагогіки вищої школи. Вісник Запорізького наиіонального університету. 2009. Вип. 2. С. 215-219.

6. Avhustiuk M. M., Pasichnyk I. D., \& Kalamazh R. V. The illusion of knowing in metacognitive monitoring: Effects of the type of information and of personal, cognitive, metacognitive, and individual psychological characteristics. Europe's Journal of Psychology. 2018. Vol. 14(2). Pp. 317-341.

7. Barron B. J. S., Schwartz D. L., Vye N. J., Moore A., Petrosino A., Zech L., Bransford J. D. Doing with understanding: Lessons from research on problem- and project-based learning. The Journal of the Learning Sciences. 1998. Vol. 7, No. 3-4. Pp. 271-311.

8. Brown A. L., Bransford J. D., Ferrara R. A., Campione J. C. Learning, remembering, and understanding. Technical Report. No. 244. 1982. 257 p.

9. Serra M. J., Metcalfe J. Effective implementation of metacognition / In D. J. Hacker, J. Dunlosky, A. C. Graesser (Eds.), Handbook of Metacognition and Education. New York, NY: Routledge, 2009. Pp. 278-298. 